Scientific Journal of Silesian University of Technology. Series Transport Zeszyty Naukowe Politechniki Śląskiej. Seria Transport

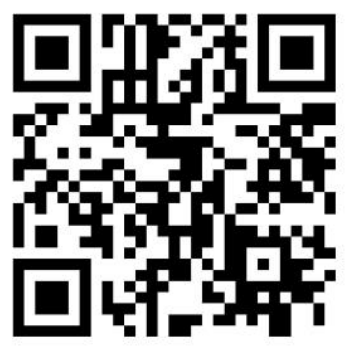

Volume 111

2021

p-ISSN: 0209-3324

e-ISSN: 2450-1549

DOI: https://doi.org/10.20858/sjsutst.2021.111.5

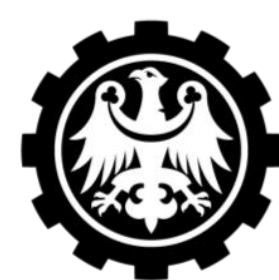

Silesian

University of Technology

Journal homepage: http://sjsutst.polsl.pl

Article citation information:

Gorzelanczyk, P., Wojtasik, M. Research on air pollutant emissions from transport sources in Pila. Scientific Journal of Silesian University of Technology. Series Transport. 2021, 111, 57-74. ISSN: 0209-3324. DOI: https://doi.org/10.20858/sjsutst.2021.111.5.

Piotr GORZELANCZYK ${ }^{1}$, Maja WOJTASIK ${ }^{2}$

\title{
RESEARCH ON AIR POLLUTANT EMISSIONS FROM TRANSPORT SOURCES IN PILA
}

Summary. This article aims to examine the emission of pollutants utilising transport in different points of the city in question at two different intervals, then show whether the means of transport negatively affects the city through pollution. The study of air pollutant emissions from transport sources is a key aspect towards solving problems related to environmental pollution. A study on the measurements of selected PM10 and PM2.5 pollutants to be able to determine the quality of air from transport sources in Pila at different times of the year and with appropriate assumptions regarding the appropriate distance by the road is included in this article. This study analysed data on air pollutants and compared it with the results of the Chief Inspectorate for Environmental Protection. This made it possible to propose solutions for the development of the air condition in Pila.

Keywords: air pollution, transport, exhaust gas emissions, transport sources, environmental protection, smog, internal combustion engines

\footnotetext{
${ }^{1}$ Stanislaw Staszic State School of Higher Vocational Education in Pila, Podchorazych 10 Street, 64-920 Pila. Poland. Email: piotr.gorzelanczyk@ puss.pila.pl. ORCID: https://orcid.org/0000-0001-9662-400X

${ }^{2}$ Stanislaw Staszic State School of Higher Vocational Education in Pila, Podchorazych 10 Street, 64-920 Pila. Poland. Email: majawojtasik134@gmail.com. ORCID: https://orcid.org/0000-0001-8323-6286
} 


\section{INTRODUCTION}

Air pollution is substances that take various forms, come from an anthropogenic source or are the result of human activity. Air pollution has a strong impact on the environment and human health; it causes many diseases for the respiratory and circulatory systems. The elderly, people with respiratory problems and children are the most endangered by polluted air. The main reason places have polluted air is because of high traffic due to exhaust emissions. Therefore, air quality programmes are being introduced to prevent further deterioration of air quality.

This article aims to present places in Pila that are most endangered by the emission of air pollutants from transport sources. For this purpose, an appropriate device for measuring PM10 and PM2.5 pollutants was used for the study, and then the measurements were compared with data from the Chief Inspectorate for Environmental Protection (CIEP). The tests were carried out in eight locations in Pila with the appropriate assumptions regarding the specified distances by road during measurement. Based on the obtained measurement results, charts were made to present the value of pollutants and show how the pollutants changed at a specific time and on a specific day, and proposed directions for improving the air quality in Pila.

\section{AIR POLLUTION}

Air pollution plays an important role in the functioning of the environment and negatively affects the health of society $[3,10,13,16,22]$. These are substances in solid, liquid or gaseous form, which may be derived from a natural source or result from human activity (anthropogenic origin). They include carbon dioxide, sulfur dioxide, nitrogen oxide and dust [20].

Air pollution is influenced by various factors that cause changes in the atmosphere. They include dust, gas and aerosol contamination of suspended liquid particles [17].

Due to the type of air pollution, there is primary and secondary pollution. Primary pollutants occur in the air in the form in which they were directly released into the atmosphere. However, secondary pollutants are not emitted from sources; they arise in the atmosphere from chemical reactions and primary pollutants [1].

The substances that pollute the air are solid, gaseous or liquid, present in the air in greater amounts than they should be. Air pollution is one of the most dangerous pollutants because it spreads very quickly and can contaminate large parts of the environment [34]. There are two sources of air pollution; pollution of natural origin and pollution of anthropogenic origin [7, 24, $32,33]$.

The most common substances that pollute the atmosphere are primarily carbon dioxide, sulfur dioxide, nitrogen oxide and dust, which are generated by the intensity of cars, fuel combustion and production processes. Sulfur dioxide $\left(\mathrm{SO}_{2}\right)$ takes a colourless form, a gas with a pungent and suffocating odour. It has a high specific gravity $\left(2.93 \mathrm{~kg} / \mathrm{m}^{3}\right.$, relative density 2.26), therefore, spreads slowly in the atmosphere. It is produced by burning large amounts of fuels containing sulfur. Sulfur dioxide can stay in the air for several days, allowing it to travel long distances. Carbon dioxide $\left(\mathrm{CO}_{2}\right)$ is a colourless gas with an odourless odour. It is produced through the combustion of solid, liquid and gaseous fuels. Carbon monoxide (CO) is colourless, odourless and flammable. It is a highly toxic gas. It can cause severe asphyxiation. This gas has an extremely low specific gravity $\left(1.25 \mathrm{~kg} / \mathrm{m}^{3}\right.$, relative density 0.97$)$, allowing it to spread easily in the atmosphere. Other substances that contribute to air pollution are nitrogen oxides (NO, $\mathrm{NO}_{2}$ ). The first is $\mathrm{NO}$, a colourless, toxic gas, and $\mathrm{NO}_{2}$, nitrogen dioxide with a brown colour 
and a suffocating odour. Nitrogen oxides are formed during the combustion of fuels at very high temperatures from cars and ships, and during energy production. They are responsible for the increased ozone content and the photochemical smog that occurs $[19,20]$.

Suspended dust (PM10, PM2.5) is a mixture of various particle diameters and chemical compositions. They are harmful to health due to the content of hazardous elements. Particulate matter is produced during the combustion of coal in combined heat and power plants, domestic stoves or during public transport, which plays important roles in everyday life. Due to the particle diameter, the following are distinguished: PM10 are fine grains with a diameter of up to 10 micrometres and PM2.5 grains with a diameter not exceeding 2.5 micrometres. Dust is a transboundary pollutant, which means that PM10 is transported up to $1000 \mathrm{~km}$, while PM2.5 is transported up to $2500 \mathrm{~km}$ [19].

Toxic exhaust fumes, which are generated while driving, also contribute to polluted air. The exhaust fumes are released from the exhaust pipes, polluting the natural environment, adversely affecting the functioning of society with attendant problems, for example, with the respiratory tract. Toxic exhaust gases include carbon monoxide (CO), hydrocarbons (HC), nitrogen oxides $\left(\mathrm{NO}_{\mathrm{x}}\right)$, sulfur oxides $\left(\mathrm{SO}_{\mathrm{x}}\right)$, solid particles $(\mathrm{PM})[25]$.

Environmental pollution is associated with the unfavourable phenomena that currently occur in the natural environment. These include smog, ozone hole, acid rain, and the greenhouse effect; all of these phenomena have an impact on the environment and human health.

The problem of air pollution caused by using transport has been analysed in many publications. Idzior et al. presented the problem related to air pollution by particulate matter PM10 and PM 2.5 in urban agglomerations [8], while Sówka [23] analysed road transport as a source of air pollution in cities [28]. The study [27] investigates the impact of pollution caused by various means of transport. And the works $[11,31]$ include the prevention of air pollution in the transport sector is important for the future improvement of air quality.

\section{AIR POLLUTION IN POLAND}

Smog in Poland is a common phenomenon, every year more cities are polluted by this phenomenon. Against the background of the European Union, Poland comes out negatively when it comes to polluted air [2]. Smog occurs cyclically, but it is most noticeable in the heating season (autumn-winter) due to many negative factors such as burning in stoves with poor quality coal, burning rubbish or rapidly developing car transport. In Poland's large cities, industrial plants, coal-fired power plants, households and transport are sources of polluted air [26].

Examples of provinces belonging to the most polluted are Sląskie and Lódzkie [29]. Pollution accumulates in highly urbanised cities; an exemplary city is Krakow. Smog in Krakow is a serious problem that negatively affects the health of its society and environment, mainly in the autumn and winter period. In 2016, in Krakow, the level of PM10 pollution for the average daily concentration standard was as high as 188 times [26].

Considering the information contained in the Directive of the European Parliament and of the Council of 21 May 2008 on cleaner air quality for Europe, the maximum allowable average annual standard for PM10 dust concentration is $40 \mu \mathrm{g} / \mathrm{m}^{3}$, and for PM2.5 it is $25 \mu \mathrm{g} / \mathrm{m}^{3}$ [12]. A summary of the annual average of the ten most polluted cities in Poland is presented in Table 1, and the ranges of permissible concentrations for individual pollutants are included in Table 2. 
Tab. 1

A comparison of the annual average of the ten most polluted cities in Poland [30]

\begin{tabular}{|c|c|c|}
\hline $\begin{array}{c}\text { City together } \\
\text { with the province }\end{array}$ & $\begin{array}{c}\text { The concentration level of } \\
\text { PM2.5 impurities }\end{array}$ & $\begin{array}{c}\text { The concentration level of } \\
\text { PM10 impurities }\end{array}$ \\
\hline Żywiec - voiv. śląskie & $43 \mu \mathrm{g} / \mathrm{m}^{3}$ & $58 \mu \mathrm{g} / \mathrm{m}^{3}$ \\
\hline Pszczyna - voiv. śląskie & $43 \mu \mathrm{g} / \mathrm{m}^{3}$ & $58 \mu \mathrm{g} / \mathrm{m}^{3}$ \\
\hline Rybnik - voiv. śląskie & $40 \mu \mathrm{g} / \mathrm{m}^{3}$ & $53 \mu \mathrm{g} / \mathrm{m}^{3}$ \\
\hline $\begin{array}{c}\text { Wodzisław Śląski - voiv. } \\
\text { śląskie }\end{array}$ & $39 \mu \mathrm{g} / \mathrm{m}^{3}$ & $53 \mu \mathrm{g} / \mathrm{m}^{3}$ \\
\hline Opoczno - voiv. łódzkie & $39 \mu \mathrm{g} / \mathrm{m}^{3}$ & $53 \mu \mathrm{g} / \mathrm{m}^{3}$ \\
\hline $\begin{array}{c}\text { Sucha Beskidzka - voiv. } \\
\text { małopolskie }\end{array}$ & $39 \mu \mathrm{g} / \mathrm{m}^{3}$ & $53 \mu \mathrm{g} / \mathrm{m}^{3}$ \\
\hline Krakow - voiv. małopolskie & $37 \mu \mathrm{g} / \mathrm{m}^{3}$ & $51 \mu \mathrm{g} / \mathrm{m}^{3}$ \\
\hline Skawina - voiv. małopolskie & $37 \mu \mathrm{g} / \mathrm{m}^{3}$ & $51 \mu \mathrm{g} / \mathrm{m}^{3}$ \\
\hline $\begin{array}{c}\text { Nowy Sącz - voiv. } \\
\text { małopolskie }\end{array}$ & $36 \mu \mathrm{g} / \mathrm{m}^{3}$ & $50 \mu \mathrm{g} / \mathrm{m}^{3}$ \\
\hline $\begin{array}{c}\text { Niepołomice - voiv. } \\
\text { małopolskie }\end{array}$ & $36 \mu \mathrm{g} / \mathrm{m}^{3}$ & $45 \mu \mathrm{g} / \mathrm{m}^{3}$ \\
\hline
\end{tabular}

Tab. 2

The range of permissible concentrations of individual pollutants [15]

\begin{tabular}{|c|l|l|l|l|l|l|l|}
\hline $\begin{array}{c}\text { Air } \\
\text { quality } \\
\text { index }\end{array}$ & $\begin{array}{c}\mathbf{P M 1 0} \\
{\left[\mu \mathrm{g} / \mathbf{m}^{3}\right]}\end{array}$ & $\begin{array}{c}\mathbf{P M 2 , 5} \\
{\left[\mu \mathrm{g} / \mathbf{m}^{\mathbf{3}}\right]}\end{array}$ & $\begin{array}{c}\mathbf{O}_{3} \\
{\left[\mu \mathrm{g} / \mathbf{m}^{3}\right]}\end{array}$ & $\begin{array}{c}\mathbf{N O}_{2} \\
{\left[\mu \mathrm{g} / \mathbf{m}^{3}\right]}\end{array}$ & $\begin{array}{c}\mathbf{S O}_{2} \\
{\left[\mu \mathrm{g} / \mathbf{m}^{3}\right]}\end{array}$ & $\begin{array}{c}\mathbf{C}_{\mathbf{6}} \mathbf{H}_{\mathbf{6}} \\
{\left[\mu \mathrm{g} / \mathbf{m}^{3}\right]}\end{array}$ & $\begin{array}{c}\mathbf{C O} \\
{\left[\mathbf{m g} / \mathbf{m}^{3}\right]}\end{array}$ \\
\hline $\begin{array}{c}\text { Very } \\
\text { good }\end{array}$ & $0-20$ & $0-13$ & $0-70$ & $0-40$ & $0-50$ & $0-6$ & $0-3$ \\
\hline Good & $20.1-50$ & $13.1-35$ & $70.1-120$ & $40.1-100$ & $50.1-100$ & $6.1-11$ & $3.1-7$ \\
\hline Moderate & $50.1-80$ & $35.1-55$ & $\begin{array}{l}120.1- \\
150\end{array}$ & $100.1-150$ & $100.1-200$ & $11.1-16$ & $7.1-11$ \\
\hline Sufficient & $\begin{array}{l}80.1- \\
110\end{array}$ & $55.1-75$ & $\begin{array}{l}150.1- \\
180\end{array}$ & $150.1-200$ & $200.1-350$ & $16.1-21$ & $11.1-15$ \\
\hline Bad & $110.1-$ & $75.1-110$ & $180.1-$ & $200.1-400$ & $350.1-500$ & $21.1-51$ & $15.1-21$ \\
\hline Very bad & $>150$ & $>110$ & $>240$ & $>400$ & $>500$ & $>51$ & $>21$ \\
\hline
\end{tabular}

Referring to the above-mentioned annual average for the ten most polluted cities in Poland, we noted that the obtained measurements exceed the maximum permissible dust concentrations specified in the directive. The main reason for air pollution is low emissions, which is related to the heating of apartments, and transport and industry contribute to exceeding the standards. 


\section{METHODS OF TESTING AIR POLLUTANT EMISSIONS FROM TRANSPORT SOURCES}

Each city or country in the world deals with the improvement of air quality with the help of a fixed measurement station that analyses and measures the level of PM10, PM2.5 particulate matter and other air pollutants. The methodology of these measurements is included in the Directive of the European Parliament and of the Council of 21 May 2008 on ambient air quality and cleaner air for Europe [6]. The rules for the location of measuring stations are also indicated in the Regulation of the Minister of the Environment of 13 September 2012 on the assessment of the levels of substances in the air [21].

The Inspection of Environmental Protection uses two methods to measure suspended dust: the gravimetric method and the reference method. The advantages of these methods are a very high accuracy and the automatic methods. These methods are equivalent to the gravimetric method. The gravimetric (manual) method is performed for 24 hours; it consists of the use of dust collectors wherein filters are placed to suck the air. Every two weeks, 14 disposable filters are put on and the device changes them automatically. Before inserting the filter into the extractor, the filters are weighed and reweighed after 14 days in the laboratory. On this basis, the dust concentrations are calculated. This method is used in Poland, Europe and the United States. However, in the automatic method, automatic metres which measure the concentration of dust on an ongoing basis are used, thanks to which we can obtain a given measurement result every hour [15].

Currently, there is one measuring station in Pila belonging to the Chief Inspector of Environmental Protection. It measures individual pollutants (PM10, $\left.\mathrm{NO}_{2}, \mathrm{CO}\right)$ and is located on Kusocinski Street. The measuring station is shown in Figure 1.

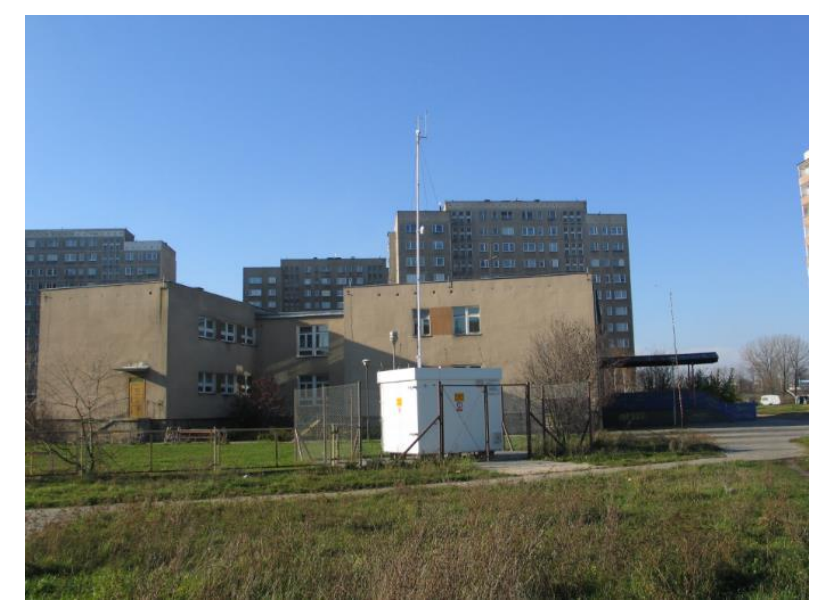

Fig. 1. Measuring station in Pila at Kusocinskiego Street [4]

\section{RESEARCH}

\subsection{Purpose of research}

This study aimed to measure air pollutant emissions from transport sources in eight places in the city of Pila. The Laser Air Quality Monitor-SDL607 device (Figure 2) was used to perform the measurements, designed to measure specific pollutants (PM10 and PM2.5). 
The sensor is designed to measure PM2.5 and PM10 dust, measure pollutants using laser light and collect air samples that were analysed. The sensor has the parameters listed in Table 3.

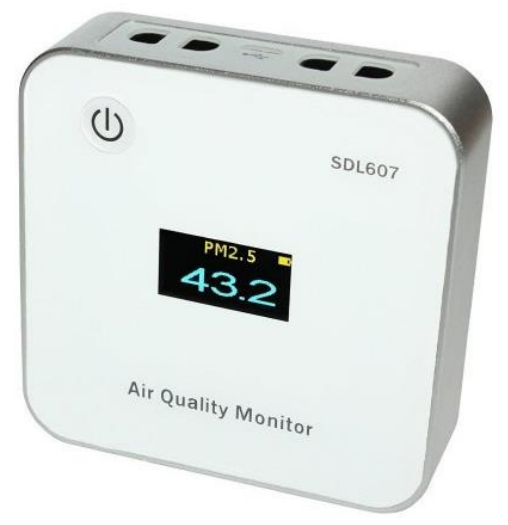

Fig. 2. Laser Air Quality Monitor - SDL607 [18]

Tab. 3

SDL607 device parameters [18]

\begin{tabular}{|l|c|}
\hline \multicolumn{2}{|c|}{ SDL607 device parameters } \\
\hline PM2.5 measurement range & $0-999.9 \mu \mathrm{g} / \mathrm{m}^{3}$ \\
\hline PM2.5 resolution & $0.1 \mu \mathrm{g} / \mathrm{m}^{3}$ \\
\hline The detection range of the PM10 & $0-999.9 \mu \mathrm{g} / \mathrm{m}^{3}$ \\
\hline PM10 resolution & $0.1 \mu \mathrm{g} / \mathrm{m}^{3}$ \\
\hline The minimum size of the detected particle & $0.3 \mu \mathrm{g} / \mathrm{m}^{3}$ \\
\hline
\end{tabular}

\subsection{Subject of study}

The subject of this research is the emission of air pollutants from transport sources in Pila, it aims to show that road transport is a significant source of environmental pollution, harmful to human health. This study was carried out in the city of Pila, and precisely in 8 selected places, the measurements were compared between individual places and the overall results from the CIEP measuring station. The places where the tests were carried out and the location of the CIEP measuring station are presented in the figure below.

Pila is a city in northwestern Poland, in the Wielkopolska Province, Pilski County. Most of which are forests, parks and lakes. It belongs to a city with a well-developed technical infrastructure. Thanks to it, there are many opportunities for the development of the economy. In the Pila poviat, the electronic industry, agri-food processing and tourism are available, which are important elements for visiting tourists due to the landscape views. There are also shopping and service centres. Pila is located near national roads no. 10 and 11 and provincial roads no. 179, 180 and 188. It crosses the road and railroads leading from the coast to the south, to Poznań, Gorzów, and even Germany, and from Szczecin and Świnoujście to Bydgoszcz, Toruń and Warsaw. In 2011, the construction of the bypass in Pila was completed; the bypass was to improve traffic between settlements, bypassing the city itself. Furthermore, it is worth mentioning the well-developed railway infrastructure, which enables connection with major Polish cities. The city's infrastructure provides its inhabitants with good living conditions, which increases the standard of living [9]. 


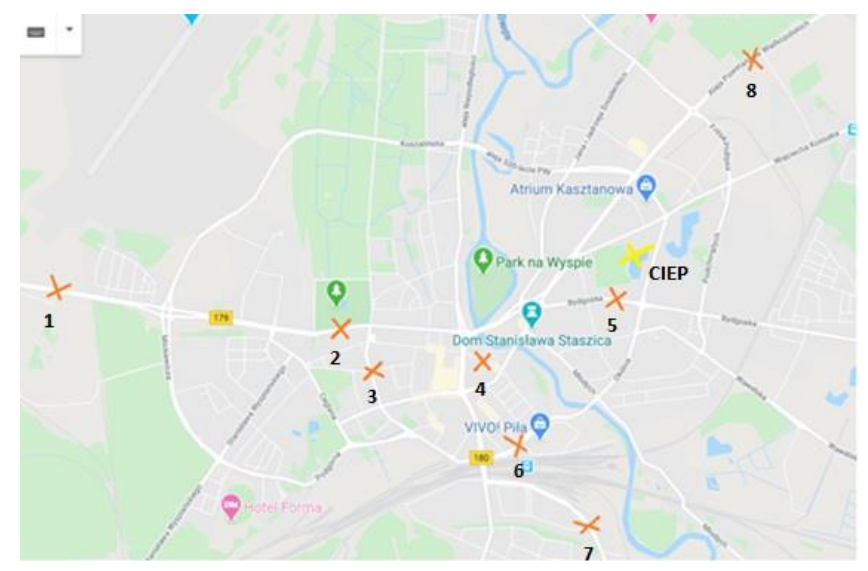

Fig. 3. Map of Pila with marked places of the performed examination [14]

When selecting places in Pila for the study of air pollutant emissions from transport sources, specific factors were considered, such as heavy traffic, the very centre of the city, places near shopping malls, schools, supermarkets, streets leading to the city of Pila, as well as streets surrounded by single-family houses. On this basis, the emission of pollutants in the city of Pila was analysed.

The study was divided into two stages: the first stage concerned measurements made at the turn of November and December, and the second stage, in February and March. Measurements were taken 24 hours a day, seven days a week for each point selected. Measurements were made on both sides of the street, on the left and on the right, considering the specified distances: at the very edge of the street, $1 \mathrm{~m}$ from the street, $2 \mathrm{~m}, 3 \mathrm{~m}$ and $4 \mathrm{~m}$. During the test, accompanying measurements were made too, such as traffic volume, traffic conditions atmospheric conditions (wind force, direction and pressure). Figure 4 shows the scheme of making measurements relative to the road while maintaining appropriate distances.

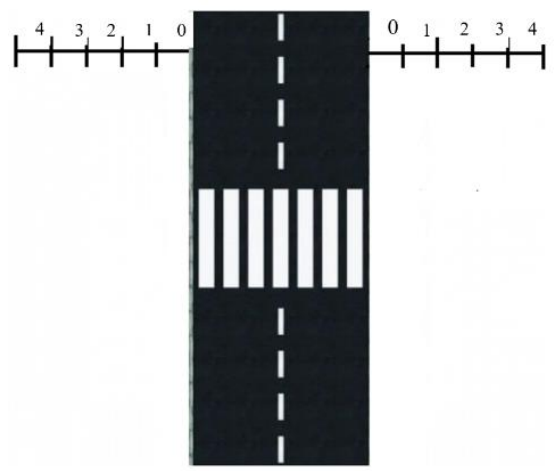

Fig. 4. Diagram of the road with defined distances when taking measurements [5]

\subsection{Findings}

The first stage of the research was carried out at the turn of November and December, and the second stage in February and March, in eight selected locations in Pila. The measurement results are presented in the table below, divided into PM2.5 and PM10 pollutants. During the research, measurements for PM10 pollution were analysed by the measurement station in Pila - CIEP. In addition, the strength and direction of the wind, pressure and traffic volume per 1 
hour were considered, and the results of PM10 were compared with the results of CIEP. Data are the weekly average for each sampling point and the specified pollutant.

Tab. 4

Weekly average of measurements for PM2.5 pollution for the first series of measurements

\begin{tabular}{|c|c|c|c|c|c|c|c|c|}
\hline $\begin{array}{c}\text { Measurement } \\
\text { point/time }\end{array}$ & Point 1 & Point 2 & Point 3 & Point 4 & Point 5 & Point 6 & Point 7 & Point 8 \\
\hline $\mathbf{0 0 : 0 0}$ & 16.06 & 13.59 & 23.40 & 16.88 & 24.84 & 18.39 & 26.62 & 21.84 \\
\hline $\mathbf{0 1 : 0 0}$ & 15.80 & 13.00 & 20.31 & 18.35 & 21.59 & 18.88 & 24.13 & 19.49 \\
\hline $\mathbf{0 2 : 0 0}$ & 16.71 & 12.35 & 17.87 & 16.55 & 19.02 & 16.56 & 21.91 & 17.39 \\
\hline $\mathbf{0 3 : 0 0}$ & 15.04 & 10.64 & 17.43 & 16.22 & 18.73 & 15.97 & 21.94 & 16.53 \\
\hline $\mathbf{0 4 : 0 0}$ & 14.37 & 9.72 & 21.56 & 15.38 & 21.54 & 14.51 & 25.80 & 19.58 \\
\hline $\mathbf{0 5 : 0 0}$ & 14.63 & 9.42 & 21.21 & 16.00 & 23.19 & 15.79 & 26.73 & 21.38 \\
\hline $\mathbf{0 6 : 0 0}$ & 15.85 & 10.45 & 20.14 & 17.06 & 22.91 & 15.95 & 26.29 & 20.37 \\
\hline $\mathbf{0 7 : 0 0}$ & 16.10 & 11.75 & 17.43 & 17.17 & 20.42 & 15.81 & 24.00 & 19.12 \\
\hline $\mathbf{0 8 : 0 0}$ & 16.08 & 13.03 & 17.96 & 17.60 & 20.76 & 17.18 & 25.87 & 20.35 \\
\hline $\mathbf{0 9 : 0 0}$ & 15.61 & 13.64 & 20.58 & 16.85 & 22.89 & 17.76 & 26.93 & 20.54 \\
\hline $\mathbf{1 0 : 0 0}$ & 16.06 & 15.75 & 21.05 & 18.96 & 25.96 & 18.58 & 29.61 & 20.96 \\
\hline $\mathbf{1 1 : 0 0}$ & 17.95 & 17.46 & 19.53 & 19.80 & 25.45 & 18.65 & 28.65 & 21.62 \\
\hline $\mathbf{1 2 : 0 0}$ & 18.96 & 18.92 & 18.18 & 20.47 & 23.77 & 19.87 & 27.05 & 22.29 \\
\hline $\mathbf{1 3 : 0 0}$ & 19.48 & 14.69 & 16.69 & 23.04 & 21.31 & 19.74 & 26.16 & 18.29 \\
\hline $\mathbf{1 4 : 0 0}$ & 18.10 & 14.03 & 13.58 & 19.20 & 16.50 & 17.50 & 20.69 & 17.83 \\
\hline $\mathbf{1 5 : 0 0}$ & 16.66 & 15.95 & 12.97 & 18.52 & 14.79 & 16.25 & 20.28 & 16.58 \\
\hline $\mathbf{1 6 : 0 0}$ & 18.48 & 14.56 & 15.24 & 21.60 & 19.22 & 17.30 & 24.83 & 19.54 \\
\hline $\mathbf{1 7 : 0 0}$ & 20.35 & 15.95 & 18.22 & 21.74 & 22.59 & 19.88 & 29.92 & 22.47 \\
\hline $\mathbf{1 8 : 0 0}$ & 19.58 & 16.35 & 20.41 & 20.28 & 25.44 & 19.76 & 33.34 & 25.62 \\
\hline $\mathbf{1 9 : 0 0}$ & 20.93 & 18.83 & 23.57 & 22.09 & 27.59 & 22.22 & 35.24 & 26.58 \\
\hline $\mathbf{2 0 : 0 0}$ & 21.13 & 20.84 & 26.66 & 21.45 & 29.36 & 24.56 & 36.68 & 28.90 \\
\hline $\mathbf{2 1 : 0 0}$ & 20.24 & 22.80 & 25.51 & 22.22 & 28.95 & 23.01 & 33.39 & 27.71 \\
\hline $\mathbf{2 2 : 0 0}$ & 19.80 & 20.48 & 24.45 & 20.80 & 27.33 & 24.09 & 30.93 & 27.45 \\
\hline $\mathbf{2 3 : 0 0}$ & 18.40 & 22.82 & 24.73 & 20.01 & 27.59 & 22.88 & 33.07 & 29.83 \\
\hline & & & & & & & & \\
\hline
\end{tabular}

Tab. 5

Weekly average of measurements for PM10 pollution for points 1-4 for the first series of measurements

\begin{tabular}{|c|c|c|c|c|c|c|c|c|c|c|c|c|}
\hline \multirow[b]{2}{*}{$\begin{array}{c}\text { Measure- } \\
\text { ment } \\
\text { point / } \\
\text { time }\end{array}$} & \multicolumn{3}{|c|}{ Point 1} & \multicolumn{3}{|c|}{ Point 2} & \multicolumn{3}{|c|}{ Point 3} & \multicolumn{3}{|c|}{ Point 4} \\
\hline & Results & CIEP & $\begin{array}{c}\text { Stan } \\
\text { dard } \\
\text { devia } \\
\text { tion } \\
\end{array}$ & Results & CIEP & $\begin{array}{c}\text { Stan } \\
\text { dard } \\
\text { devia } \\
\text { tion } \\
\end{array}$ & Results & CIEP & $\begin{array}{c}\text { Stan } \\
\text { dard } \\
\text { devia } \\
\text { tion } \\
\end{array}$ & Results & CIEP & $\begin{array}{c}\text { Stan } \\
\text { dard } \\
\text { devia } \\
\text { tion }\end{array}$ \\
\hline 00:00 & 22.24 & 31.77 & 6.73 & 17.34 & 23.50 & 4.35 & 26.54 & 29.12 & 1.82 & 22.39 & 29.10 & 4.75 \\
\hline 01:00 & 22.44 & 30.10 & 5.41 & 17.10 & 21.90 & 3.39 & 23.27 & 25.68 & 1.71 & 22.87 & 28.25 & 3.80 \\
\hline
\end{tabular}


$\underline{\text { Research on air pollutant emissions from transport sources in Pila }}$

\begin{tabular}{|c|c|c|c|c|c|c|c|c|c|c|c|c|}
\hline 02:00 & 21.07 & 26.73 & 4.00 & 15.10 & 19.17 & 2.88 & 21.41 & 24.22 & 1.98 & 22.00 & 25.45 & 2.44 \\
\hline 03:00 & 19.36 & 26.28 & 4.90 & 13.00 & 19.30 & 4.45 & 20.11 & 20.45 & 0.24 & 21.16 & 23.38 & 1.57 \\
\hline 04:00 & 19.60 & 24.56 & 3.51 & 12.61 & 14.60 & 1.40 & 23.99 & 20.30 & 2.61 & 20.70 & 2.33 & 1.15 \\
\hline 05:00 & 20.27 & 25.23 & 3.51 & 12.89 & 14.38 & 1.06 & 24.41 & 21.89 & 1.79 & 2.36 & 2.93 & 0.40 \\
\hline 06:00 & 21.87 & 23.53 & 1.17 & 12.94 & 15.67 & 1.93 & 23.04 & 20.63 & 1.71 & 22.44 & 21.76 & 0.48 \\
\hline 07:00 & 21.60 & 25.08 & 2.46 & 15.73 & 17.55 & 1.29 & 21.80 & 19.30 & 1.77 & 22.77 & 3.93 & 0.82 \\
\hline 08:00 & 21.33 & 25.02 & 2.61 & 17.54 & 18.93 & 0.98 & 22.07 & 20.39 & 1.19 & 22.36 & 25.00 & 1.87 \\
\hline 09:00 & 20.27 & 25.37 & 3.60 & 18.64 & 18.58 & 0.04 & 23.80 & 21.76 & 1.44 & 22.06 & 25.60 & 2.51 \\
\hline 10:00 & 22.39 & 17.75 & 3.28 & 20.10 & 17.34 & 1.95 & 24.69 & 20.10 & 3.24 & 23.74 & 20.53 & 2.27 \\
\hline 11:00 & 23.89 & 19.27 & 3.27 & 23.99 & 19.23 & 3.36 & 23.33 & 23.93 & 0.43 & 24.94 & 25.05 & 0.08 \\
\hline 12:00 & 23.56 & 19.35 & 2.97 & 24.17 & 18.89 & 3.74 & 21.89 & 16.26 & 3.98 & 24.70 & 24.68 & 0.01 \\
\hline 13:00 & 24.1 & 20 & 2.83 & 19 & 16 & 2.22 & 19 & 11 & 5.67 & 7 & 13 & 3.00 \\
\hline 14:00 & 22.71 & 18.40 & 3.05 & 17.17 & 14.11 & 2.16 & 14.90 & 13.50 & 0.99 & 26.01 & 18.66 & 5.20 \\
\hline 15:00 & 22.17 & 17.04 & 3.63 & 15.61 & 13.01 & 1.84 & 14.70 & 12.04 & 1.88 & 22.81 & 16.27 & 4.63 \\
\hline 16:00 & 23.57 & 18.70 & 3.44 & 17.66 & 12.67 & 3.53 & 17.04 & 16.40 & 0.45 & 24.00 & 19.04 & 3.51 \\
\hline 17:00 & 25.20 & 21.14 & 2.87 & 20.39 & 15.23 & 3.65 & 20.43 & 21.04 & 0.43 & 26.74 & 23.13 & 2.56 \\
\hline 18:00 & 23.37 & 22.96 & 0.29 & 20.43 & 18.53 & 1.34 & 22.31 & 25.10 & 1.97 & 26.04 & 25.63 & 0.29 \\
\hline 19:00 & 25.14 & 27.49 & 1.66 & 21.29 & 21.76 & 0.33 & 26.47 & 27.77 & 0.92 & 28.21 & 29.34 & 0.80 \\
\hline 20:00 & 26.81 & 28.96 & 1.52 & 24.14 & 25.20 & 0.75 & 29.87 & 31.07 & 0.85 & 28.20 & 30.69 & 1.76 \\
\hline 21:00 & 24.73 & 26.44 & 1.21 & 25.61 & 25.57 & 0.03 & 28.14 & 31.54 & 2.40 & 27.77 & 30.09 & 1.64 \\
\hline 22:00 & 24.83 & 23.33 & 1.06 & 24.80 & 26.20 & 0.99 & 27.87 & 32.53 & 3.29 & 26.21 & 27.93 & 1.21 \\
\hline 23:00 & 22.79 & 21.37 & 1.00 & 25.93 & 29.78 & 2.73 & 28.29 & 33.86 & 3.94 & 24.87 & 26.06 & 0.84 \\
\hline
\end{tabular}

Tab. 6

Weekly average of measurements for PM10 pollution for points 5-8 for the first series of measurements

\begin{tabular}{|c|c|c|c|c|c|c|c|c|c|c|c|c|}
\hline \multirow{2}{*}{$\begin{array}{c}\text { Measure- } \\
\text { ment } \\
\text { point } / \\
\text { time }\end{array}$} & Results & CIEP & $\begin{array}{c}\text { Point 5 } \\
\text { dard } \\
\text { devia } \\
\text { tion }\end{array}$ & Results & CIEP & $\begin{array}{c}\text { Point 6 } \\
\text { dard } \\
\text { devia } \\
\text { tion }\end{array}$ & Results & CIEP & $\begin{array}{c}\text { Stan } \\
\text { dard } \\
\text { devia } \\
\text { tion }\end{array}$ & Results & CIEP & $\begin{array}{c}\text { Stan } \\
\text { dard } \\
\text { devia } \\
\text { tion }\end{array}$ \\
\hline $\mathbf{0 0 : 0 0}$ & 27.19 & 30.92 & 2.64 & 23.29 & 30.48 & 5.09 & 27.93 & 30.92 & 2.11 & 25.47 & 29.63 & 2.94 \\
\hline $\mathbf{0 1 : 0 0}$ & 23.19 & 25.82 & 1.86 & 22.44 & 29.08 & 4.70 & 25.37 & 25.82 & 0.31 & 22.03 & 24.80 & 1.96 \\
\hline $\mathbf{0 2 : 0 0}$ & 21.64 & 25.17 & 2.49 & 20.16 & 25.33 & 3.66 & 23.54 & 25.17 & 1.15 & 20.94 & 23.77 & 2.00 \\
\hline $\mathbf{0 3 : 0 0}$ & 21.04 & 21.43 & 0.28 & 19.16 & 24.47 & 3.75 & 24.56 & 21.43 & 2.21 & 19.80 & 19.62 & 0.13 \\
\hline $\mathbf{0 4 : 0 0}$ & 24.19 & 19.27 & 3.47 & 18.07 & 22.19 & 2.91 & 28.32 & 19.27 & 6.40 & 21.43 & 16.90 & 3.20 \\
\hline $\mathbf{0 5 : 0 0}$ & 26.01 & 20.46 & 3.93 & 19.20 & 22.51 & 2.34 & 29.19 & 20.46 & 6.18 & 23.84 & 17.74 & 4.31 \\
\hline $\mathbf{0 6 : 0 0}$ & 26.27 & 21.83 & 3.14 & 19.20 & 20.94 & 1.23 & 28.59 & 21.83 & 4.78 & 24.48 & 19.24 & 3.71 \\
\hline $\mathbf{0 7 : 0 0}$ & 23.30 & 21.99 & 0.93 & 20.60 & 22.53 & 1.37 & 27.65 & 21.99 & 4.00 & 23.90 & 19.80 & 2.90 \\
\hline $\mathbf{0 8 : 0 0}$ & 24.49 & 21.94 & 1.80 & 22.36 & 23.37 & 0.71 & 28.75 & 21.94 & 4.81 & 23.70 & 20.53 & 2.24 \\
\hline $\mathbf{0 9 : 0 0}$ & 26.07 & 22.39 & 2.61 & 21.83 & 23.72 & 1.34 & 30.91 & 22.39 & 6.03 & 24.28 & 20.97 & 2.34 \\
\hline $\mathbf{1 0 : 0 0}$ & 29.18 & 26.14 & 2.15 & 21.89 & 14.77 & 5.03 & 32.67 & 26.14 & 4.61 & 25.72 & 23.59 & 1.51 \\
\hline
\end{tabular}




\begin{tabular}{|c|c|c|c|c|c|c|c|c|c|c|c|c|}
$\mathbf{1 1 : 0 0}$ & 29.70 & 27.71 & 1.40 & 21.93 & 16.60 & 3.77 & 31.72 & 27.71 & 2.83 & 26.01 & 25.43 & 0.41 \\
\hline $\mathbf{1 2 : 0 0}$ & 27.11 & 20.38 & 4.76 & 23.84 & 17.58 & 4.43 & 30.32 & 20.38 & 7.03 & 24.50 & 18.62 & 4.16 \\
\hline $\mathbf{1 3 : 0 0}$ & 24.20 & 16.20 & 5.66 & 23.94 & 17.73 & 4.39 & 29.10 & 16.20 & 9.12 & 24.31 & 13.82 & 7.42 \\
\hline $\mathbf{1 4 : 0 0}$ & 19.29 & 16.81 & 1.75 & 21.29 & 16.20 & 3.60 & 23.92 & 16.81 & 5.03 & 24.21 & 14.61 & 6.78 \\
\hline $\mathbf{1 5 : 0 0}$ & 18.04 & 17.07 & 0.69 & 20.06 & 14.41 & 3.99 & 22.65 & 17.07 & 3.94 & 21.85 & 14.44 & 5.23 \\
\hline $\mathbf{1 6 : 0 0}$ & 21.80 & 20.40 & 0.99 & 19.64 & 15.27 & 3.09 & 26.83 & 20.40 & 4.55 & 23.74 & 16.97 & 4.79 \\
\hline $\mathbf{1 7 : 0 0}$ & 25.61 & 23.46 & 1.53 & 23.11 & 18.37 & 3.35 & 30.77 & 23.46 & 5.17 & 25.31 & 20.69 & 3.27 \\
\hline $\mathbf{1 8 : 0 0}$ & 28.14 & 26.30 & 1.30 & 22.79 & 21.11 & 1.18 & 33.93 & 26.30 & 5.40 & 29.12 & 24.46 & 3.30 \\
\hline $\mathbf{1 9 : 0 0}$ & 30.16 & 28.59 & 1.11 & 23.10 & 25.30 & 1.56 & 36.54 & 28.59 & 5.62 & 30.88 & 26.40 & 3.17 \\
\hline $\mathbf{2 0 : 0 0}$ & 32.34 & 30.49 & 1.31 & 27.56 & 28.31 & 0.54 & 38.74 & 30.49 & 5.83 & 31.78 & 29.84 & 1.37 \\
\hline $\mathbf{2 1 : 0 0}$ & 31.29 & 29.87 & 1.00 & 27.34 & 27.06 & 0.20 & 34.79 & 29.87 & 3.48 & 31.70 & 30.49 & 0.86 \\
\hline $\mathbf{2 2 : 0 0}$ & 29.59 & 29.76 & 0.12 & 28.30 & 26.27 & 1.43 & 33.27 & 29.76 & 2.48 & 32.02 & 32.70 & 0.48 \\
\hline $\mathbf{2 3 : 0 0}$ & 31.36 & 30.37 & 0.70 & 26.53 & 25.06 & 1.04 & 35.66 & 30.37 & 3.74 & 34.45 & 34.06 & 0.28 \\
\hline
\end{tabular}

After analysing the obtained measurements, it can be observed that the degree of pollution did not reach the maximum, bad value assumed for PM10 $>200 \mu \mathrm{g} / \mathrm{m}^{3}$, and PM2.5 > $120 \mu \mathrm{g} / \mathrm{m}^{3}$. The pollution level was classified to the level of moderate and good quality. Comparing the obtained measurements with the measurements from CIEP, we observed that they were varied, everything depended on the day and the factors contributing to it. The highest values were achieved in the mornings and evenings, where the heating of houses contributed the most to the pollution level, in winter, it is normal that more coal was burned in domestic stoves. Exhaust emissions also contributed to higher values, sometimes in rush hours, the values increased, depending on which street the pollutant emissions were measured on. The values were much higher from Monday to Friday than on weekends. After analysing the measurements, we observed that the values were greater when measuring the measurements along the road, whereas the further we moved away, the smaller the values became, the reason for this was the escaping exhaust fumes, that is, they had a shorter distance to the device used to measure the measurements. The exception was point 7 , the measured values on the right side were the opposite, that is, the closer to the road, the smaller the value, and the further it is, the reason for this are single-family houses located there. The results from CIEP were similar to the results in point 5 , due to its proximity to the measurement.

The wind force had a great influence on the measurement value because the higher the wind force, the lower the pollution value, as then the dust was blown by the wind and the pollution did not accumulate around itself. Moreover, the amount of traffic influenced the amount of pollution.

The second stage of the research was carried out at the turn of February and March. As in the first measurement, during the research, measurements for PM10 pollution were similarly analysed by the measurement station in Pila - CIEP. In addition, the strength and direction of the wind, pressure and traffic volume per 1 hour were considered, and the standard deviation from the given measurements was calculated as well. Data are the weekly mean for every single point and the specified pollutant. 
$\underline{\text { Research on air pollutant emissions from transport sources in Pila }}$ 67

Tab. 7

Weekly average of measurements for PM2.5 pollution for the second series of measurements

\begin{tabular}{|c|c|c|c|c|c|c|c|c|}
\hline $\begin{array}{c}\text { Measurement } \\
\text { point/time }\end{array}$ & Point 1 & Point 2 & Point 3 & Point 4 & Point 5 & Point 6 & Point 7 & Point 8 \\
\hline $\mathbf{0 0 : 0 0}$ & 10.87 & 11.70 & 10.83 & 12.30 & 10.77 & 11.25 & 11.15 & 10.48 \\
\hline $\mathbf{0 1 : 0 0}$ & 12.03 & 14.25 & 14.62 & 12.55 & 11.87 & 14.24 & 12.90 & 11.73 \\
\hline $\mathbf{0 2 : 0 0}$ & 11.64 & 13.76 & 11.31 & 13.48 & 12.28 & 10.25 & 12.80 & 11.40 \\
\hline $\mathbf{0 3 : 0 0}$ & 10.20 & 11.86 & 12.42 & 12.91 & 12.46 & 10.83 & 13.26 & 10.50 \\
\hline $\mathbf{0 4 : 0 0}$ & 9.71 & 13.70 & 12.24 & 11.36 & 11.45 & 13.74 & 12.32 & 9.31 \\
\hline $\mathbf{0 5 : 0 0}$ & 10.64 & 11.07 & 11.61 & 10.20 & 10.42 & 12.06 & 10.71 & 9.50 \\
\hline $\mathbf{0 6 : 0 0}$ & 10.10 & 11.29 & 11.21 & 9.01 & 9.34 & 11.88 & 10.92 & 9.74 \\
\hline $\mathbf{0 7 : 0 0}$ & 9.76 & 10.41 & 12.32 & 8.82 & 9.62 & 12.04 & 11.61 & 8.27 \\
\hline $\mathbf{0 8 : 0 0}$ & 9.83 & 12.40 & 15.11 & 9.87 & 9.48 & 14.73 & 11.71 & 9.02 \\
\hline $\mathbf{0 9 : 0 0}$ & 12.89 & 13.33 & 15.19 & 11.38 & 9.88 & 16.28 & 12.08 & 9.86 \\
\hline $\mathbf{1 0 : 0 0}$ & 11.59 & 11.44 & 14.37 & 8.97 & 9.20 & 14.89 & 11.40 & 8.26 \\
\hline $\mathbf{1 1 : 0 0}$ & 9.82 & 11.66 & 11.83 & 9.21 & 8.26 & 12.68 & 10.80 & 8.09 \\
\hline $\mathbf{1 2 : 0 0}$ & 9.81 & 11.23 & 11.44 & 8.93 & 8.68 & 12.24 & 10.96 & 7.98 \\
\hline $\mathbf{1 3 : 0 0}$ & 9.79 & 11.14 & 11.70 & 11.07 & 9.74 & 12.43 & 12.12 & 9.19 \\
\hline $\mathbf{1 4 : 0 0}$ & 9.38 & 11.68 & 12.03 & 12.50 & 8.70 & 14.55 & 10.89 & 10.44 \\
\hline $\mathbf{1 5 : 0 0}$ & 10.31 & 11.66 & 12.34 & 12.62 & 10.17 & 14.21 & 11.16 & 10.47 \\
\hline $\mathbf{1 6 : 0 0}$ & 8.90 & 10.56 & 10.44 & 12.21 & 9.60 & 12.73 & 10.80 & 9.20 \\
\hline $\mathbf{1 7 : 0 0}$ & 8.59 & 10.64 & 11.03 & 9.95 & 8.91 & 12.25 & 10.51 & 8.19 \\
\hline $\mathbf{1 8 : 0 0}$ & 8.64 & 10.70 & 11.45 & 11.44 & 9.85 & 12.80 & 11.22 & 8.89 \\
\hline $\mathbf{1 9 : 0 0}$ & 11.64 & 13.37 & 12.51 & 11.07 & 11.01 & 11.66 & 13.40 & 8.95 \\
\hline $\mathbf{2 0 : 0 0}$ & 14.53 & 15.82 & 15.02 & 11.14 & 11.79 & 16.32 & 15.97 & 10.20 \\
\hline $\mathbf{2 1 : 0 0}$ & 14.42 & 17.31 & 16.72 & 14.28 & 12.37 & 15.29 & 16.23 & 10.93 \\
\hline $\mathbf{2 2 : 0 0}$ & 11.80 & 14.17 & 13.39 & 13.46 & 14.05 & 12.12 & 18.30 & 13.08 \\
\hline $\mathbf{2 3 : 0 0}$ & 11.09 & 12.13 & 12.34 & 10.82 & 14.05 & 11.79 & 16.41 & 11.05 \\
\hline
\end{tabular}

Tab. 8

Weekly average of measurements for PM10 pollution for points 1-4 for the second series of measurements

\begin{tabular}{|c|c|c|c|c|c|c|c|c|c|c|c|c|}
\hline \multirow[b]{2}{*}{$\begin{array}{c}\text { Measure- } \\
\text { ment } \\
\text { point / } \\
\text { time }\end{array}$} & \multicolumn{3}{|c|}{ Point 1} & \multicolumn{3}{|c|}{ Point 2} & \multicolumn{3}{|c|}{ Point 3} & \multicolumn{3}{|c|}{ Point 4} \\
\hline & Results & CIEP & \begin{tabular}{|c|} 
Stan \\
dard \\
devia \\
tion \\
\end{tabular} & Results & CIEP & \begin{tabular}{|c|} 
Stan \\
dard \\
devia \\
tion \\
\end{tabular} & Results & CIEP & \begin{tabular}{|c|} 
Stan \\
dard \\
devia \\
tion
\end{tabular} & Results & CIEP & $\begin{array}{c}\text { Stan } \\
\text { dard } \\
\text { devia } \\
\text { tion }\end{array}$ \\
\hline 00:00 & 12.29 & 17.60 & 3.76 & 13.21 & 17.60 & 3.10 & 12.06 & 17.60 & 3.92 & 13.76 & 16.69 & 2.07 \\
\hline 01:00 & 13.73 & 19.52 & 4.09 & 16.01 & 19.52 & 2.48 & 15.79 & 19.52 & 2.64 & 14.03 & 17.89 & 2.73 \\
\hline 02:00 & 12.73 & 21.26 & 6.03 & 14.99 & 21.26 & 4.43 & 13.06 & 21.26 & 5.80 & 14.97 & 17.30 & 1.65 \\
\hline 03:00 & 11.64 & 18.01 & 4.51 & 13.04 & 18.01 & 3.52 & 13.46 & 18.01 & 3.22 & 14.26 & 17.64 & 2.39 \\
\hline 04:00 & 11.40 & 16.90 & 3.89 & 15.11 & 16.90 & 1.26 & 13.66 & 16.90 & 2.29 & 12.89 & 17.00 & 2.91 \\
\hline
\end{tabular}




\begin{tabular}{|l|l|l|l|l|l|l|l|l|l|l|l|l|}
$\mathbf{0 5 : 0 0}$ & 12.13 & 13.87 & 1.23 & 11.94 & 13.87 & 1.36 & 13.03 & 13.87 & 0.59 & 11.21 & 13.90 & 1.90 \\
\hline $\mathbf{0 6 : 0 0}$ & 11.36 & 10.66 & 0.50 & 12.91 & 10.66 & 1.60 & 12.31 & 10.66 & 1.17 & 10.26 & 12.00 & 1.23 \\
\hline $\mathbf{0 7 : 0 0}$ & 11.13 & 11.73 & 0.43 & 12.34 & 11.73 & 0.43 & 13.79 & 11.73 & 1.45 & 10.17 & 9.71 & 0.32 \\
\hline $\mathbf{0 8 : 0 0}$ & 11.97 & 15.48 & 2.48 & 14.24 & 15.48 & 0.88 & 16.47 & 15.48 & 0.70 & 11.46 & 10.26 & 0.85 \\
\hline $\mathbf{0 9 : 0 0}$ & 14.20 & 16.27 & 1.46 & 15.16 & 16.27 & 0.79 & 16.84 & 16.27 & 0.40 & 12.66 & 10.60 & 1.45 \\
\hline $\mathbf{1 0 : 0 0}$ & 13.04 & 16.93 & 2.75 & 13.07 & 16.93 & 2.73 & 15.89 & 16.93 & 0.74 & 10.34 & 11.39 & 0.74 \\
\hline $\mathbf{1 1 : 0 0}$ & 11.16 & 13.29 & 1.51 & 12.96 & 13.29 & 0.23 & 13.07 & 13.29 & 0.15 & 10.31 & 10.56 & 0.17 \\
\hline $\mathbf{1 2 : 0 0}$ & 11.09 & 11.63 & 0.38 & 12.44 & 11.63 & 0.58 & 12.77 & 11.63 & 0.81 & 10.04 & 8.16 & 1.33 \\
\hline $\mathbf{1 3 : 0 0}$ & 12.21 & 11.09 & 0.80 & 13.14 & 11.09 & 1.45 & 12.94 & 11.09 & 1.31 & 12.47 & 10.28 & 1.55 \\
\hline $\mathbf{1 4 : 0 0}$ & 13.10 & 9.99 & 2.20 & 13.59 & 9.99 & 2.55 & 13.87 & 9.99 & 2.75 & 14.11 & 11.98 & 1.51 \\
\hline $\mathbf{1 5 : 0 0}$ & 12.99 & 10.96 & 1.43 & 14.46 & 10.96 & 2.47 & 13.74 & 10.96 & 1.97 & 14.27 & 8.62 & 4.00 \\
\hline $\mathbf{1 6 : 0 0}$ & 11.59 & 10.94 & 0.45 & 13.16 & 10.94 & 1.57 & 11.84 & 10.94 & 0.64 & 14.00 & 7.89 & 4.32 \\
\hline $\mathbf{1 7 : 0 0}$ & 10.57 & 9.83 & 0.53 & 12.19 & 9.83 & 1.67 & 12.57 & 9.83 & 1.94 & 11.34 & 9.73 & 1.14 \\
\hline $\mathbf{1 8 : 0 0}$ & 9.80 & 10.13 & 0.23 & 12.16 & 10.13 & 1.43 & 12.77 & 10.13 & 1.87 & 12.74 & 9.67 & 2.17 \\
\hline $\mathbf{1 9 : 0 0}$ & 12.91 & 12.71 & 0.14 & 15.03 & 12.71 & 1.64 & 14.13 & 12.71 & 1.00 & 12.73 & 10.21 & 1.78 \\
\hline $\mathbf{2 0 : 0 0}$ & 16.07 & 17.61 & 1.09 & 17.67 & 17.61 & 0.04 & 16.73 & 17.61 & 0.63 & 12.41 & 13.14 & 0.52 \\
\hline $\mathbf{2 1 : 0 0}$ & 16.36 & 21.97 & 3.97 & 19.44 & 21.97 & 1.79 & 18.50 & 21.97 & 2.45 & 15.77 & 16.49 & 0.51 \\
\hline $\mathbf{2 2 : 0 0}$ & 13.41 & 18.11 & 3.32 & 15.91 & 18.11 & 1.56 & 15.10 & 18.11 & 2.13 & 14.83 & 14.93 & 0.07 \\
\hline $\mathbf{2 3 : 0 0}$ & 12.43 & 16.53 & 2.90 & 13.96 & 16.53 & 1.82 & 13.94 & 16.53 & 1.83 & 11.93 & 16.64 & 3.33 \\
\hline
\end{tabular}

Tab. 9

Weekly average of measurements for PM10 pollution for points 5-8 for the second series of measurements

\begin{tabular}{|c|c|c|c|c|c|c|c|c|c|c|c|c|}
\hline \multirow[b]{2}{*}{$\begin{array}{c}\text { Measure- } \\
\text { ment } \\
\text { point / } \\
\text { time }\end{array}$} & \multicolumn{3}{|c|}{ Point 5} & \multicolumn{3}{|c|}{ Point 6} & \multicolumn{3}{|c|}{ Point 7} & \multicolumn{3}{|c|}{ Point 8} \\
\hline & Results & CIEP & \begin{tabular}{|c|} 
Stan \\
dard \\
devia \\
tion
\end{tabular} & Results & CIEP & $\begin{array}{c}\text { Stan } \\
\text { dard } \\
\text { devia } \\
\text { tion }\end{array}$ & Results & CIEP & $\begin{array}{c}\text { Stan } \\
\text { dard } \\
\text { devia } \\
\text { tion }\end{array}$ & Results & CIEP & $\begin{array}{c}\text { Stan } \\
\text { dard } \\
\text { devia } \\
\text { tion } \\
\end{array}$ \\
\hline 00:00 & 12.70 & 16.69 & 2.82 & 12.47 & 17.60 & 3.63 & 13.10 & 16.69 & 2.54 & 12.13 & 16.69 & 3.22 \\
\hline 01:00 & 13.49 & 17.89 & 3.11 & 2.07 & 19.52 & 5.26 & 14.80 & \begin{tabular}{|l|}
17.89 \\
\end{tabular} & 2.18 & 3.03 & 17.89 & 3.43 \\
\hline 02:00 & 13.63 & 17.30 & 2.60 & 11.53 & 21.26 & 6.88 & 15.00 & 17.30 & 1.63 & 12.77 & 17.30 & 3.20 \\
\hline 03:00 & 13.73 & 17.64 & 2.77 & 12.23 & 18.01 & 4.09 & 15.24 & 17.64 & 1.70 & 12.20 & \begin{tabular}{|l|}
17.64 \\
\end{tabular} & 3.85 \\
\hline 04:00 & 12.64 & 17.00 & 3.08 & 14.97 & 16.90 & 1.36 & 14.39 & 17.00 & 1.85 & 10.89 & \begin{tabular}{|l|}
17.00 \\
\end{tabular} & 4.32 \\
\hline 05:00 & 11.50 & 13.90 & 1.70 & 13.03 & 13.87 & 0.59 & 12.59 & 13.90 & 0.93 & 10.79 & 13.90 & 2.20 \\
\hline 06:00 & 10.43 & 12.00 & 1.11 & 13.29 & 10.66 & 1.86 & 12.97 & 12.00 & 0.69 & 10.74 & 12.00 & 0.89 \\
\hline 07:00 & 11.06 & 9.71 & 0.95 & 13.87 & 11.73 & 1.51 & 12.96 & 9.71 & 2.29 & 9.67 & 9.71 & 0.03 \\
\hline 08:00 & 24.09 & 10.26 & 9.78 & 16.59 & 15.48 & 0.78 & 13.29 & 10.26 & 2.14 & 10.16 & 10.26 & 0.07 \\
\hline 09:00 & 11.07 & 10.60 & 0.33 & 17.57 & 16.27 & 0.92 & 13.60 & 10.60 & 2.12 & 11.17 & 10.60 & 0.40 \\
\hline 10:00 & 10.20 & 11.39 & 0.84 & 16.06 & 16.93 & 0.62 & 13.24 & \begin{tabular}{|l|}
11.39 \\
\end{tabular} & 1.31 & 9.53 & \begin{tabular}{|l|}
11.39 \\
\end{tabular} & 1.31 \\
\hline 11:00 & 9.19 & 10.56 & 0.97 & 13.80 & 13.29 & 0.36 & 12.39 & 10.56 & 1.29 & 9.40 & 10.56 & 0.82 \\
\hline 12:00 & 9.76 & 8.16 & 1.13 & 13.66 & 11.63 & 1.43 & \begin{tabular}{|l|}
12.41 \\
\end{tabular} & 8.16 & 3.01 & 9.11 & 8.16 & 0.67 \\
\hline 13:00 & 11.60 & 10.28 & 0.93 & 14.40 & 11.09 & 2.34 & 14.01 & \begin{tabular}{|l|}
10.28 \\
\end{tabular} & 2.64 & 10.64 & \begin{tabular}{|l|}
10.28 \\
\end{tabular} & 0.25 \\
\hline
\end{tabular}


Research on air pollutant emissions from transport sources in Pila

\begin{tabular}{|l|l|l|l|l|l|l|l|l|l|l|l|l|}
$\mathbf{1 4 : 0 0}$ & 10.80 & 11.98 & 0.84 & 16.54 & 9.99 & 4.64 & 12.57 & 11.98 & 0.42 & 12.43 & 11.98 & 0.31 \\
\hline $\mathbf{1 5 : 0 0}$ & 11.47 & 8.62 & 2.02 & 15.87 & 10.96 & 3.47 & 12.71 & 8.62 & 2.90 & 12.41 & 8.62 & 2.69 \\
\hline $\mathbf{1 6 : 0 0}$ & 11.11 & 7.89 & 2.28 & 14.56 & 10.94 & 2.56 & 12.49 & 7.89 & 3.25 & 11.20 & 7.89 & 2.34 \\
\hline $\mathbf{1 7 : 0 0}$ & 10.77 & 9.73 & 0.74 & 13.91 & 9.83 & 2.89 & 11.77 & 9.73 & 1.44 & 9.74 & 9.73 & 0.01 \\
\hline $\mathbf{1 8 : 0 0}$ & 11.10 & 9.67 & 1.01 & 14.63 & 10.13 & 3.18 & 12.93 & 9.67 & 2.30 & 10.40 & 9.67 & 0.52 \\
\hline $\mathbf{1 9 : 0 0}$ & 12.67 & 10.21 & 1.74 & 13.29 & 12.71 & 0.40 & 15.31 & 10.21 & 3.61 & 10.63 & 10.21 & 0.29 \\
\hline $\mathbf{2 0 : 0 0}$ & 13.36 & 13.14 & 0.15 & 18.29 & 17.61 & 0.47 & 18.36 & 13.14 & 3.69 & 11.71 & 13.14 & 1.01 \\
\hline $\mathbf{2 1 : 0 0}$ & 14.04 & 16.49 & 1.73 & 17.47 & 21.97 & 3.18 & 18.27 & 16.49 & 1.26 & 12.91 & 16.49 & 2.53 \\
\hline $\mathbf{2 2 : 0 0}$ & 15.41 & 14.93 & 0.34 & 14.03 & 18.11 & 2.89 & 19.99 & 14.93 & 3.58 & 15.41 & 14.93 & 0.34 \\
\hline $\mathbf{2 3 : 0 0}$ & 14.87 & 16.64 & 1.25 & 13.36 & 16.53 & 2.25 & 20.04 & 16.64 & 2.40 & 13.81 & 16.64 & 2.00 \\
\hline
\end{tabular}

After analysing the results, we observed a significant improvement in the air quality of PM2.5 and PM10 pollutants. Measurements made in the second stage are much lower than in the autumn-winter period (November-December). Comparing the received measurements and the measurements of CIEP, showed that they were similar. The obtained measurements from PM10 were higher than PM2.5. The level of air quality was good and very good, which is a significant improvement over the first stage. Measurements in the eight selected locations in Pila were very similar. Higher level measurements were obtained mostly in rush hours and morning hours when the traffic was much higher. The level of pollution in the evening hours was much lower than in the winter. The highest values of pollutants were noted along the road, both in the case of PM10 and PM2.5 on the left and right sides. Only in the case of point 6, the values of the measurements on the right were sometimes opposite, as was the case in the winter months due to household smoking. Of course, the weather conditions, pressure, wind direction and strength, as well as the intensity of cars, contributed to the negative functioning of the environment due to exhaust fumes from exhaust pipes, negatively affecting the air quality, also contributed to the measurement values. The differences between measurement 1 and 2 are presented in the diagrams below. Example comparison of the two stages is presented in the charts below.

Summarising the stages of the November-December and February-March studies on PM2.5 and PM10 pollutants, we noticed significant differences between the measurements. In the first stage, the measurements were much higher than in the second stage. Only in one case, during the night hours, the measurement results were more favourable in the winter. This may be due to the proximity of the park and the lack of residential buildings. Out of the eight selected places in Pila, the areas in the city centre, that is, the place next to shopping malls, schools or main roads in the city with the highest traffic density, take the highest values of pollution. The wind force was of great importance for the measurement value because the higher the wind force, the lower the pollution values were, as the dust is blown by the wind and the pollution does not accumulate around itself. The direction of the wind was also important depending on which side the wind was blowing, the values changed dynamically.

The comparison of both stages with the use of the above charts made it possible to illustrate and prove that the measurements performed in the second stage, that is, February-March, were lower than the measurements from the first stage, November-December. The main reason was the season of the year, which is home heating. 


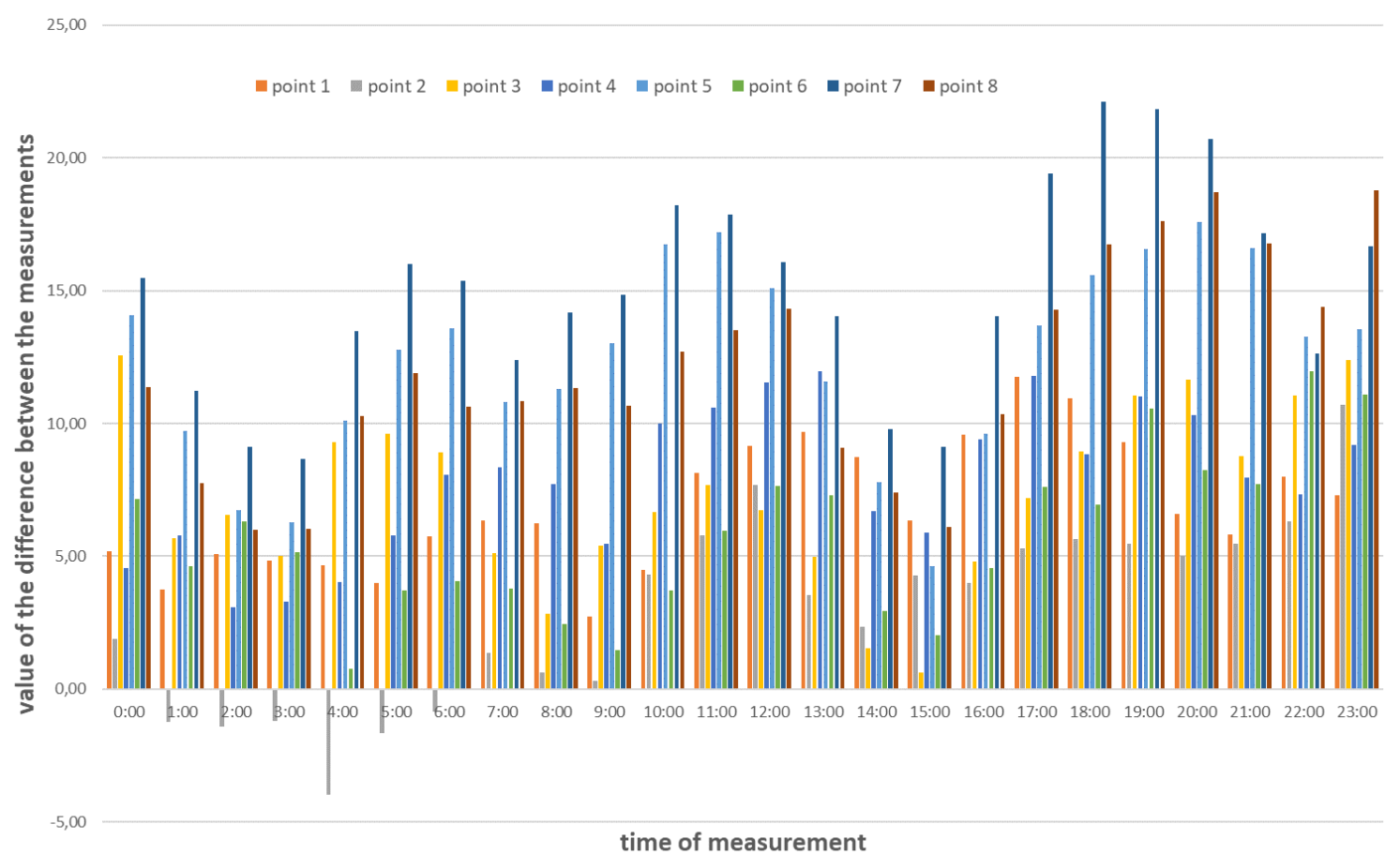

Fig. 6. Difference between measurement 1 and 2 - PM2.5

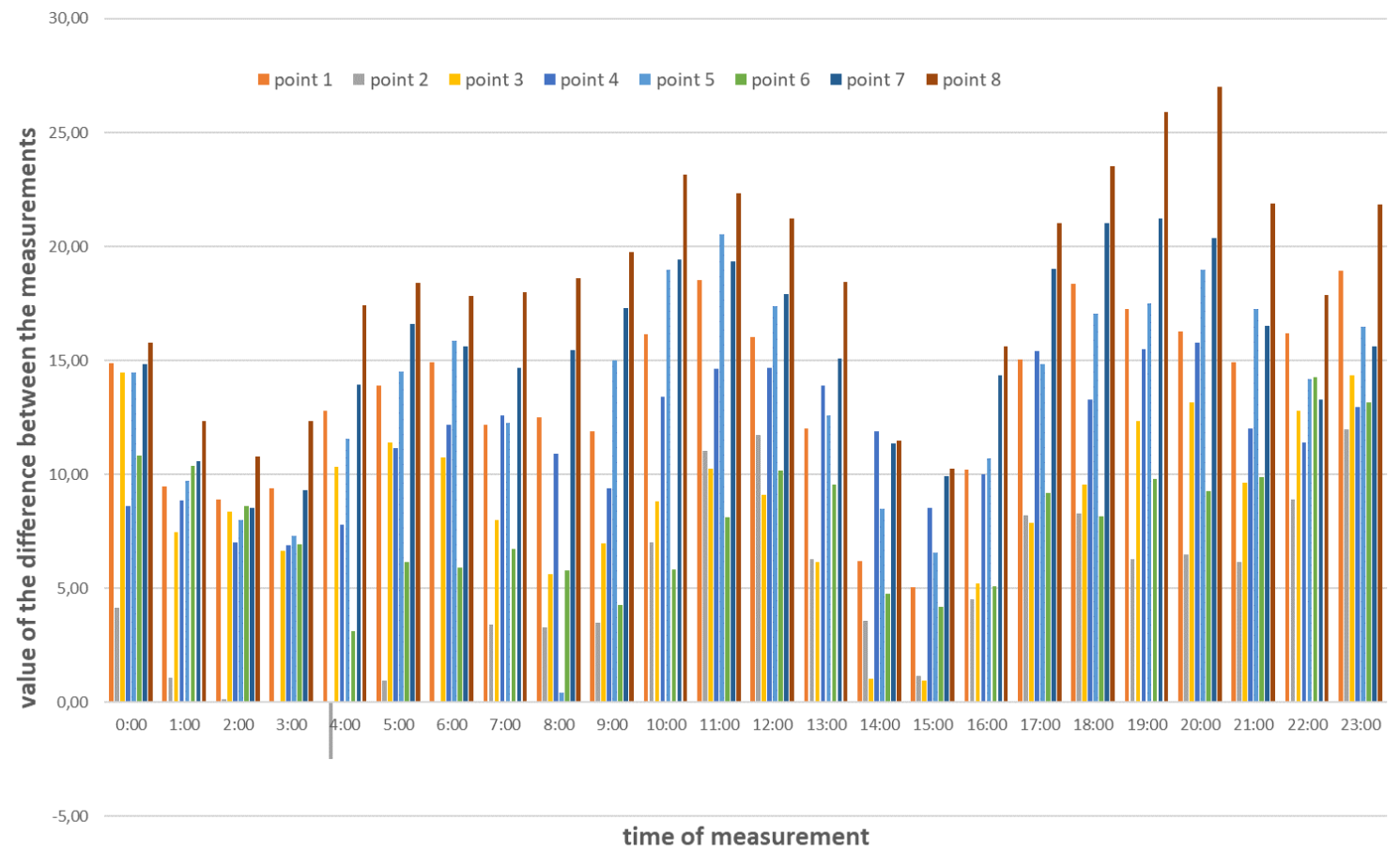

Fig. 7. Difference between measurement 1 and $2-$ PM10 


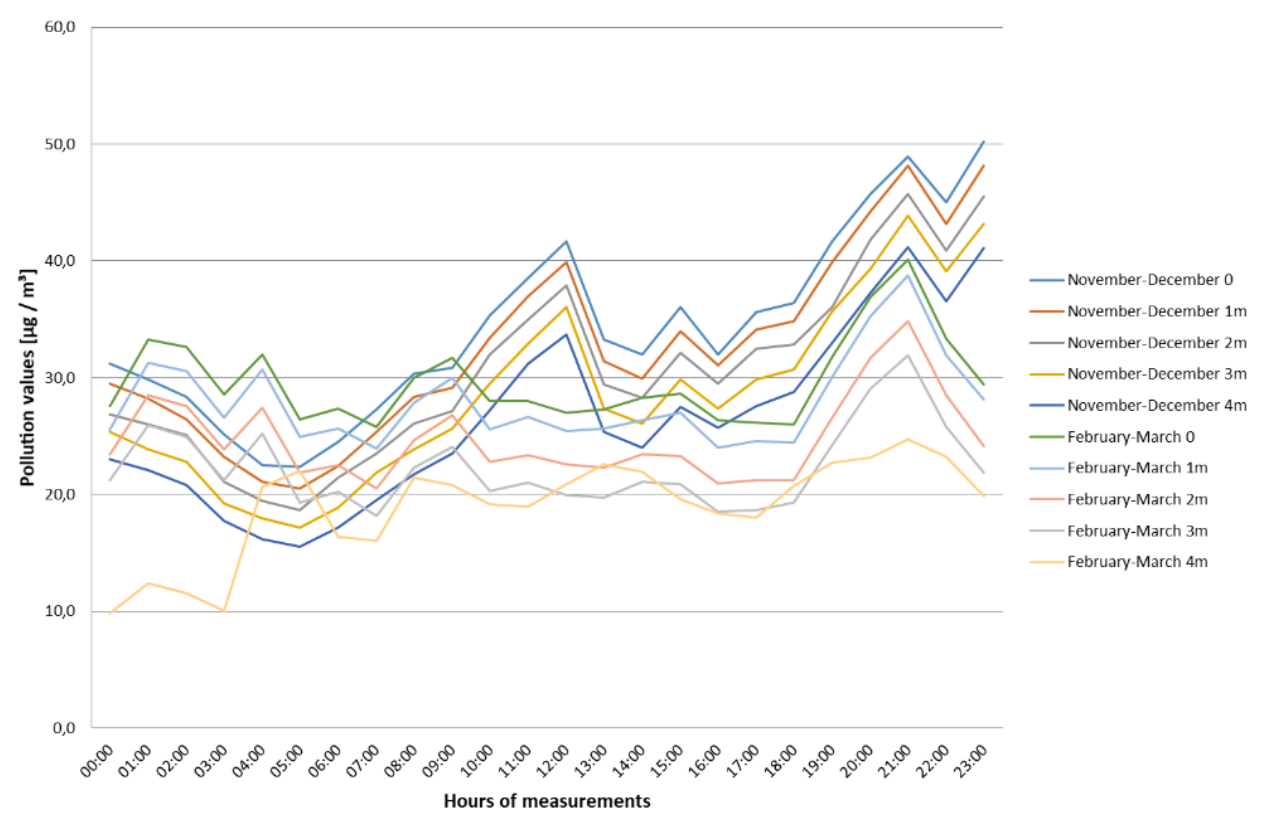

Fig. 8. Comparison of the first stage with the second stage - PM2.5 pollution for point 2

\section{CONCLUSIONS}

This article aimed to study air pollutant emissions from transport sources in Pila. This is an important and recurring environmental topic. Road transport has a huge impact on the source of air pollution. The main assumption of this work was to show the places most endangered by the emission of air pollutants, based on which it is possible to propose development directions for improving the air condition in Pila. The emission of pollutants has a decisive influence on the state of air quality. The study on air pollutant emissions from transport sources in Pila showed that there are no places particularly endangered by exhaust gas emissions in Pila. This is confirmed by the range of permissible concentrations for individual pollutants; the level was in the very good and moderate range, depending on the month of the study.

This study presents in detail selected places in Pila, which were examined 24 hours a day, 7 days a week with specific assumptions. From the conducted research, which was divided into two stages, it can be concluded that the results of the research carried out at the turn of November and December were much higher than at the turn of February and March. The main reason was the heating period. While the traffic of cars during the study was similar to each other, it is difficult to relate to the intensity of cars, which are the source of pollutant emissions. The study showed that proposals to improve the directions of air quality development should be introduced. It is a very important aspect of the environment and society, minimising the emission of pollutants is not as difficult as it seems, limiting the use of a means of transport and replacing it, for example, with a bicycle, is already to some degree related to the improvement of air quality.

\section{References}

1. Air pollution. Available at: https://encyklopedia.pwn.pl/haslo/zanieczyoszeniapowietrza;4000235.html. 
2. Adamkiewicz Lukasz, Natalia Matyasik. 2019. „Smog w Polsce i jego konsekwencje”. Working Paper 5. Warsaw: Polish Economic Institute. [In Polish: „Smog in Poland” and its consequences"].

3. Al-Mofleh Anwar, Soib Taib, Wael A. Salah. 2010. "Malaysian energy demand and emissions from the transportation sector". Transport 25(4): 448-453.

4. Data of the measuring station in Pila. Available at: http://powiekieta.gios.gov.pl/pjp/current/station_details/info/920.

5. Diagram of the roadway. Available at: https://www.cezao.pl/pl/p/Podlogowa-matajezdnia-do-nauki-poruszania-sie-po-drodze-BRD/2838.

6. Directive 2008/50/EC of the European Parliament and of the Council of May 21. 2008 on ambient air quality and cleaner air for Europe. Journal of Laws UE L 152 of June 11. 2008.

7. Ekologia: czasem po dymie poznasz, czym sąsiad pali. Available at: http://nettg.pl/news/140549/ekologia-czasem-po-dymie-poznasz-czego-sasiad-pali/ [In Polish: Ecology: sometimes you can tell by the smoke what your neighbor is smoking].

8. Idzior Marek, Edward Czapliński, Mateusz Bor. 2017. „Wpływ transportu samochodowego na zanieczyszczenie powietrza pyłem zawieszonym PM10 i PM 2,5". Autobusy: technika, eksploatacja, systemy transportowe 6. [In Polish: „Impact of road transport on air pollution by PM10 and PM2.5 dust"].

9. Infrastruktura w mieście Piła. Available at: https://www.powiat.pila.pl/opowiecie/informacje/infrastruktura. [In Polish: Infrastructure in the city of Piła].

10. Jacyna M., J. Merkisz. "Proecological approach to modelling traffic organization in national transport system". Archives of Transport 2(30): 43-56.

11. Li X., Q. Zhang, Y. Zhang, B. Zheng, K. Wang, Y. Chen, T.J. Wallington, W.J. Han, W. Shen, X.Y. Zhang, et al. 2015. "Source contributions of urban PM2.5 in the BeijingTianjinHebei region: Changes between 2006 and 2013 and relative impacts of emissions and meteorology". Atmos. Environ. 123: 229-239.

12. Łyczko Piotr. Jakość powietrza w Polsce na tle Unii Europejskiej. Available at: https://powietrze.malopolska.pl/baza/jakosc-powietrza-w-polsce-na-tle-unii-europejskiej/. [In Polish: Air quality in Poland compared to the European Union].

13. Makan Hemisha, Gert J. Heyns. 2018. „Sustainable supply chain initiatives in reducing greenhouse gas emission within the road freight industry". Journal of Transport and Supply Chain Management 12(a365): 1-10. ISSN 2310-8789.

14. Mapa Piły. Available at: https://www.google.pl/maps/place/Pi\%C5\%82a/data=!4m2!3m1!1s0x4703e43e19ce785d :0x64dc72cbc93a28bd?sa=X\&ved=2ahUKEwiJwp-

S1_fpAhUulosAQH8hUulosAQH8gUulosAccess. [In Polish: Map of the town of Piła].

15. Metody pomiaru zanieczyszczeń. Available at: https://powietrze.gios.gov.pl/pjp/content/show/1000919. [In Polish: Methods of measuring].

16. Mickevicius T., S. Slavinskas, S. Wierzbicki, K. Duda. 2014. „,The effect of dieselbiodiesel blends on the performance and exhaust emissions of a direct injection off-road diesel engine". Transport 29(4): 440-448.

17. Niemiec Witold, Sylwia Sadowska, Oktavia Niemiec. 2010. Wybrane zagadnienia ochrony środowiska w turystyce. Rzeszów: Publishing House of the Rzeszów University of Technology. [In Polish: Selected issues of environmental protection in tourism]. 
18. Operating manual of the device - Laser Air Quality Monitor SDL607.

19. Podstawowa charakterystyka zanieczyszczeń powietrza. Available at: http://www.ekoprognoza.pl/index.php?id=120\&id2=114 [In Polish: Basic characteristics of air pollutants].

20. Pyłka-Gutowska Ewa. 2004. Ekologia z ochrona środowiska. Oświata Publishing House. 2004. [In Polish: Ecology with environmental protection].

21. Rozporządzenie Ministra Środowiska z dnia 13 września 2012 r. w sprawie dokonywania oceny poziomów substancji w powietrzu. Dz.U. 2012 poz. 1032 [In Polish: Regulation of the Minister of the Environment of September 13. 2012 on assessing the levels of substances in the air. Journal of Laws of 2012. items 1032. 1119].

22. Schmidt Marie, Stefan Voss. 2017. „Advanced systems in public transport”. Public Transport 9(1-2) Special Issue: 3-6.

23. Sówka Izabela. 2017. „Transport drogowy jako źródło zanieczyszczenia powietrza w miastach". Czysta Energia 1-2. [In Polish: "Road transport as a source of air pollution in cities"].

24. Szczepańska Joanna. Działalność człowieka, a środowisko cz. II. Available at: https://www.wios.lodz.pl/files/docs/r07xiix 18.pdf/. [In Polish: Human activity and the environment part. II].

25. Toksyczność spalin. Available at: https://docplayer.pl/3867501-Laboratorium-podstawsilnikow-i-napedow-spalinowych-cwiczenie-6-diagnostyczne-pomiary-toksycznychskladnikow-spalin.html. [In Polish: Toxicity of exhaust gases].

26. Wojtal Remigiusz. 2004. „Zanieczyszczenie powietrza w miastach w aspekcie ruchu drogowego". Transport miejski i regionalny. [In Polish: "Air pollution in cities in terms of road traffic"].

27. Yang D.Y., S.J. Zhang, T.L. Niu, Y.J. Wang, H.L. Xu, K.M. Zhang, Y. Wu. 2019. "Highresolution mapping of vehicle emissions of atmospheric pollutants based on large-scale real-world traffic datasets". Atmos. Chem. Phys. 19: 8831-8843.

28. Yifeng Xue, Cao Xizi, Ai Yi, Xu Kangli, Zhang Yichen. 2020. "Primary Air Pollutants Emissions Variation Characteristics and Future Control Strategies for Transportation Sector in Beijing, China”. Sustainability 12(10): 4111. DOI: https://doi.org/10.3390/su12104111.

29. Zanieczyszczone miasta. Available at: https://300gospodarka.pl/news/raport-29-ze-100najMost-zanieczyszczonych-miast-europy-jest-w-polsce. [In Polish: Polluted cities].

30. Zanieczyszczone powietrze w Polsce. Available at: https://alertsmogowy.pl/rankingi/qfmt/najbrudszym-powiekieta-w-polsce-ranking2019.html. [In Polish: Polluted air in Poland].

31. Zhang S.J., Y. Wu, X.M. Wu, M.L. Li., Y.S. Ge, B. Liang, Y.Y. Xu, Y. Zhou, H. Liu, L.X. Fu, et al. 2014. "Historic and future trends of vehicle emissions in Beijing. 19982020: A policy assessment for the most stringent vehicle emission control program in China". Atmos. Environ. 89: 216-229.

32. Źródła zanieczyszczeń powietrza, pochodzenie antropogeniczne. Available at: https://www.niebieskiatmoludek.pl/wp-content/uploads/2014/04/prezentacja_warszatatynauczyciele-20141.pdf/. [In Polish: Sources of air pollution, anthropogenic origin].

33. Źródła zanieczyszczeń powietrza, pochodzenie naturalnego. Available at: https://encyklopedia.pwn.pl/haslo/zanieczyoszenia-powietrza; 4000235/. [In Polish: Sources of air polluoisetion, natural origin]. 
34. Źródła zanieczyszczeń. Available at:

https://www.oddechtozycie.pl/2019/10/15/zrodlazanieczyszczeniapowietrza/. [In Polish: Sources of air pollution].

Received 28.01.2021; accepted in revised form 09.04.2021

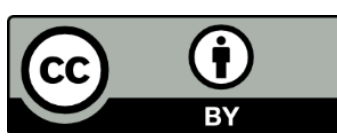

Scientific Journal of Silesian University of Technology. Series Transport is licensed under a Creative Commons Attribution 4.0 International License 